\title{
Concept of Faith: Its Ontological and Gnoseological Aspects*
}

\author{
Sergei Nizhnikov \\ Department of the History of Philosophy \\ Peoples' Friendship University of Russia \\ Moscow, Russia \\ E-mail: nizhnikovs@mail.ru
}

\begin{abstract}
The concept of faith is defined as a universal path to the spiritual knowledge born in the "Axial Age" (K. Jaspers) as a way of understanding the transcendent origins underlying all the world religions and associated philosophies. The author of the article asserts the significance of faith from the philosophical, epistemological and social perspectives, analyzes the relation of faith and knowledge, and determines the dependence of the said relation from the ontological attitude (pantheism, transcendentalism, etc.).
\end{abstract}

Keywords—faith; knowledge; metaphysics of faith; fideism; pantheism; transcendentism

\section{INTRODUCTION}

The spiritual and moral nature of faith emerges in the "Axial Age" when there is a breakthrough to the transcendent sphere, as an idea of "super existential benevolent origin" is born. For K. Jaspers, faith is the "realization of the existence from its origin"; "true faith is the act of existence, realizing the transcendence in its reality"; "faith is the perception of existence in its correlation with the transcendence" [1]. However, we should consider not the philosophical faith as the faith of philosophizing subjects, but the philosophy of faith as an ontological science of the spiritual foundations of existence. By reflecting on and experiencing the faith, philosophy tracks back to its ancient purpose and definition - which is the healer of soul and love for wisdom, overcoming the Scientist temptations and regaining the metaphysical essence. Although, in the broad sense, faith permeates the human consciousness, all aspects of his activities and being, and all social interactions. Faith is not a purely religious phenomenon, it is present in science - a scientist, putting forward a hypothesis, believes in it. In the interpersonal relations, we call a friend a person someone whom we trust, whom we believe.

Knowledge is truth, existing objectively, not demanding a personal participation. Faith is subjective and absolute for an individual. It, being essentially incomprehensible, gives meaning to everything that can be proved. True faith is a living spiritual process of human self-creative work. Faith is a spiritual fire, igniting itself in the process of self-knowing

*Disclosure: The publication has been prepared with the support of the "RUDN University Program 5-100" in the framework of the scientific project "Religion as a factor of stability of modern Russian society". and deployment of human nature. It is something inherent to a human being and, to use the philosophical language, has an ontological, a priori nature. In a varying degree, faith is present in every person, revealing itself in the development of the personal spiritual realization.

\section{THE RATIONALE AND CONCEPT OF FAITH}

Faith is a universal phenomenon from both the cultural studies' point of view and the presence in human consciousness. Therefore, Fyodor Dostoyevsky, Mircea Eliade, and Erich Fromm argued that all people are believers being different only in "object" of their faith. Faith is also necessary from the Weltanschauung and gnoseological standpoints, as knowledge is always limited in explanation of the world around, so it is complemented with faith. Without it, Weltanschauung is incomplete, filled with all sorts of superstitions that are so widespread among the modern "enlightened" people. In this sense, as emphasized by the aforementioned philosophers, atheism is impossible because an object of a person's belief is the Absolution, which could be called both God and matter (as it performs the same function as God in religion, generating and defining everything). A leader, a certain social system, money and selfish desires may also be idolized: every individual chooses his own god to worship. Yet, faith in the transcendent origin destroys all forms of idolatry because nothing finite is worthy of adoration. Faith is the basis of all world religions and associated philosophy.

The phenomenon of faith in the transcendent origin should be comprehended as a spiritual act that should be subjected to philosophical reflection. In that case, philosophy should not be built over the original religious experience, turning into the handmaid of theology (by constructing a religious philosophy). It should also not substitute the phenomenon of faith with reason (by constructing a philosophy of religion). Faith is a special kind of "academic ignorance" (Nicholas of Cusa), gnosis or knowing, speculatively seeking the meaning of life and being one of the direct, primary and sustainable methods of spiritual perception.

In completely different cultures, we can detect virtually identical observations on faith and its necessity. In the Analects of Confucius, e.g., we may read the following 
notion: "I do not know how a man without truthfulness is to get on. How can a large carriage be made to go without the cross-bar for yoking the oxen to, or a small carriage without the arrangement for yoking the horses?" [2]. In the Indian epos Bhagavad Gita: "But sacrifice for gain, offered for good repute, be sure that this, o Best of Bharatas" [3]. In Christianity, Paul the Apostle defines faith as "the evidence of things not seen" [Epistle to the Hebrews, 11:1]. Ivan Kireyevsky states, that "a man is his faith" [4]. Faith is also defined as "the experience of freedom" (G. Florovsky, S. Bulgakov), as transcendence (V. Nesmelov, D. Bonhoeffer), and as a way to eternity: "He that believeth on me hath everlasting life" (John, 6:47).

Anthony the Great reveals the content of the phenomenon of faith through the concept of eternity, and the spirituality is born from the relation of a person to eternity: "All that is ours is nothing compared to eternal life... and the Earth is small compared to the Heavens". F. Dostoyevsky considers faith in the immortality of the soul as a necessary condition of morality. If, after death, there is only a "burdock on a grave" (ref. I. Turgenev's Bazarov), then morality couldn't be redeemed, as shown by I. Kant in his ethical works, while returning to the notions. This was previously denied in Critique of Pure Reason. Thus, an idea of immortality is born, being identified in Christianity with the concept of Kingdom of Heaven. The stated concepts are often understood in the spirit of enlightened naturalism: first, they are perceived as sensual reality and then are torn down as lacking empirical evidence. This approach doesn't have anything philosophical in it, testifying of a superficial and vulgar perception of spiritual truths. The latter is of a speculative nature, as evidenced by the following Evangelic quotation: "... the kingdom of God is within you" (Luke, 17:21). Faith as a method of "superrational", speculative cognition can't beget naturalistic images, although speaking the same language. This language is purely symbolic and requires a corresponding decoding, which could be done only by a spiritual philosophy or metaphysics of faith [5].

Faith bestows immortality, for it directs attention, thinking, and contemplation on the higher, eternal occurrences. If the mind thinks of eternity, it acquires the quality (Plato, Aristotle). It doesn't matter if a person is a disciple or an atheist: they both have faith, one - in the truth of the commandments, the second - in morality. Yet, the basis of any morality - as for secular or religious - is faith. Morality may only be based on absolute principles and axioms, which are difficult to prove. Friedrich Jacobi noted that "a human has a sense for the supersensuous", that "Faith is confidence in what we do not see. We do not see the absolution, we believe in it. We see the deterministic and relative, calling this vision knowledge. Here is the realm of science"; "Faith is the basis of virtue" [6].
I.V. Kireyevsky considers faith as the condition of integrity: "faith ... is not a special concept of mind or heart, it doesn't fit into any cognitive ability, logical mind, cordial feeling, or counsel of conscience, but embraces the entire wholeness of a human being and manifests only in the moment of wholeness and in proportion to its fullness. Therefore, the main character of the disciple's thinking is in the desire to collect all the separate parts of a soul into one sole power, to seek out the inner focus of existence, where reason, will, feeling, consciousness, beauty, true, wonderful, desirable, just, merciful, and the volume of mind fuse into one living unity, thus restoring a significant personality of a human in his indivisibility" [7]. G. Florovsky also points out, that "Faith is not a transient, fleeting state of a human soul, and its constant and certain tonos is integrity or the entirety of the spirit" [8].

\section{ONTOLOGICAL AND GNOSEOLOGICAL ASPECTS OF FAITH AND KNOWLEDGE RELATION}

There is a lot of confusion from various sides regarding the faith and knowledge relation. Although, this issue was essentially solved in a high-quality philosophical and theological literature.

The breadth of faith and its superiority to knowledge was offered already in the works of Augustine of Hippo: "What I understand, that I also believe, although I do not also understand everything I believe. Also, everything I understand, I know, though I do not know everything I believe. Nor do I for that reason fail to see how useful it is also to believe many things which I do not know..." (The Teacher, XI).

Clement of Alexandria for the first time pushes forward the idea that constitutes the foundation of all subsequent metaphysical thought - the harmony of faith and knowledge: "There is no knowledge without faith, there is also no faith without knowledge" (Strom. V 177). What's deep and extensive is the understanding of faith and knowledge relation in the Russian philosophy. V.V. Nesmelov gnoseologically defined faith as "immediate intuitive cognition of transcendent reality" [9]. V.V. Sokolov writes "between the intellectual sphere, from which proceeds deduction, and the emotional sphere, representing the origin of induction, lies frequently intuition, uniting these two spheres". Intuition concentrates the defining fundamental quality of philosophical knowledge, which the author calls "faith-knowing" [10].

The faith and knowledge relation can be represented in the following four logical options, arising from the certain types of philosophical Weltanschauung, metaphysics: 
1. Naturălym and materialism
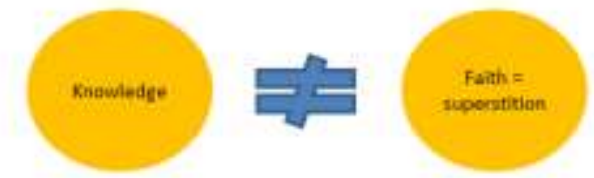

4. Absolite transcendentiam,

Soleinm and aposticion

(Tetullian, L Strestow)
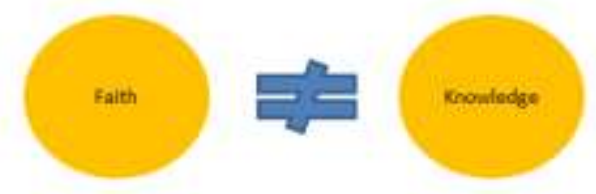

2. Pantheism (Hegel), panentheism (Schelling), Christian Platonism (P. Florensky , S. Frank)

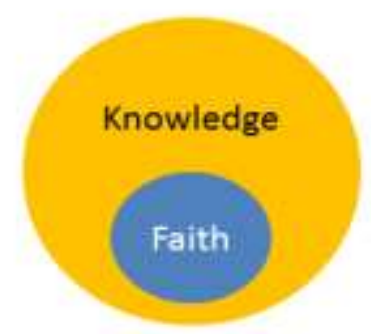

3. Metaplysics of faith $\mathrm{C}$. Nesmelov, G. Forovsky, V. Zenkovsky, V, Lossky)

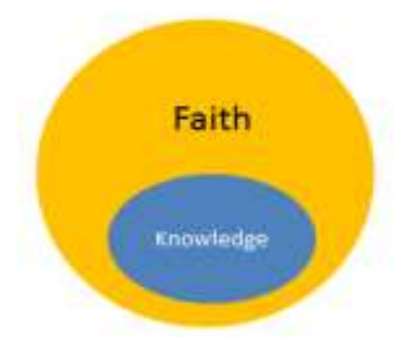

Fig. 1. The faith and knowledge relation.

In the first case, knowledge denies faith, which is identified with superstition. This may include all kinds of naturalism - positivism, materialism, etc., as well as rationalism, drawn from sensualism, recognizing only what it is able to comprehend and denying everything unknown and incomprehensible. It is the reason, unaware of its limitations and forced to deny everything spiritual, because it is not perceived by the senses.

In the second case, knowledge absorbs faith, thereby destroying its specificity, especially indicative in this respect is the position of G.W.F. Hegel. According to him, everything is comprehensible, even God, so faith itself is simply unnecessary. Faith can be present only there, where it doesn't beam the light of reason. Although the German philosopher criticizes the rational philosophy, suggesting the speculative method, he hasn't gone far from the lack of understanding the peculiarity of faith. This is due to his dynamic pantheism, that doesn't recognize anything transcendent. God, Absolution is the world, taken in its entirety.

In the third case, faith includes knowledge, absorbing it but not negating. Faith doesn't deny reason but expands its boundaries. The only reason, transcending one's own boundaries, being aware of its limitations, may open itself to faith and acquire it. "Faith is the conviction in the heart, the knowledge", - writes Al-Ghazali. For Maximus the Confessor, "Faith is the unprovable knowledge". According to S. Bulgakov, "Faith doesn't limit the mind, which should know its boundaries" [11] [12].
In the fourth case, faith, denying knowledge, degenerates into superstition. F.W.J. Schelling developed an even more sophisticated version of pantheism, when God is not in the world (as in naturalistic pantheism of B. Spinoza, for example), but the world is in God (mystical pantheism, stemming from Nicholas of Cusa and Meister Eckhart). Yet, the general pantheistic setting remains, missing a breakthrough in the sphere of the transcendent. This is wellunderstood and criticized by F. Jacobi. He shows that rationalism, seeking to build a coherent ideological system, inevitably leads to pantheism. So, challenging inevitable in pantheistic metaphysics rationalism and determinism, Jacobi notes: "The causality principle doesn't lead beyond nature, i.e. the assembly of finitude. In order to transcend the limits of nature, one may leave the limits of causality: it doesn't allow the action to beget itself. It is inconceivable to the mind" [13]. Hegel replaced in his logical ontology metaphysics of eternity with the dialectical temporary process, creating a system of determinism and impersonalism.

Historically, the first rigorously developed pantheism was Neoplatonism, which was intellectually and spiritually challenged by Christianity, ultimately winning the battle in the first centuries $\mathrm{AD}$. Due to this victory, modern civilization exists. Otherwise, the ancient world would have continued to exist, and the barbarism persisted. Nowadays, we are losing the fruits of victory and surrendering to the enemy - hence the world wars, global issues, moral and spiritual degradation. We may entitle this to the fact that, in the pantheistic framework, it is impossible to justify the theodicy, establish the moral: evil is seen as a necessary 
component of the universe and not as something filthy, that should not exist.

Pantheism is the only rational view of the world, which naturally leads to the further ideological degradation in materialism. This path was also taken by the modern European philosophy. At the level of human life - this is the priority of material values. In order to break through the vicious circle of rationalism, an individual first needs a spiritual breach which could only be done through faith. From the standpoint of rationalism, it is impossible to speak of the transcendent at all, as it is a product of faith and not logic. Logic could not implement a "vertical mobility"; it could only go around the circle. A spiritual breakthrough can bring logic to a different level, but it is already a different logic, basing on other foundations. Paul the Apostle commented beautifully on the wisdom of the world and faith, which is insanity to reason.

In fact, pantheism and all its varieties, just like Neoplatonism, lack transcendentism. There is a concept of super-existentiality as the periphery of religions and the corresponding philosophy. But only the transcendent concepts make possible, in particular, the logical rationale of human freedom, virtue, and the value of human life. Otherwise, it dissolves in nature, and in the sphere of ethics occurs a loss of a clear division of good and evil, which leads to the destruction of morality - this has already happened in Neoplatonism and Gnosticism. A.F. Losev: "Neoplatonism exactly came to a complete legalization of all that is happening in the world, to the full legality of evil... This is the extreme level of comprehension of the deities as reflections of material forces of nature and society" [14].

Pantheism and transcendentalism are ideologically opposite. It is possible to connect them, only subordinating one to the other. An attempt to join them leads to eclecticism. Though there were principled critics of pantheism in the West, one of the most brilliant representatives of which was F. Jacobi. This is what he writes on the occasion, echoing Blaise Pascal: "... we are interested in only the living God as a supreme being, creating the world from the thoughts and freedom. Blindly acting nature is not God. "I profess Christianity..." He, who deifies nature - denies God" [15].

If the failure of Neoplatonism was revealed by the Holy Fathers and Christian philosophers, F. Jacobi struggles with the new European pantheism, reanimating the moves of its ancient predecessor. The criticism of Jacobi is specifically aimed at Benedictus (Baruch) de Spinoza, who is considered to be a classic pantheist. Jacobi witnessed the ideas of Spinoza gaining strength in the German philosophy, influencing Hegel, Schelling, Lessing, and Schleiermacher: "Spinoza mixed nature with God. His world is forever permanent. A meaningless world, in which all things, including people, are, in essence, a fleeting nothing.

"Implicit", undefined "wholeness" and God - are two absolutely different concepts. The inexhaustible fruitfulness of nature and the creation of the world by God - are two different phenomena. The ideas of Spinoza, just like "logical emanatism", whether pagan or Judaic, - are atheistic ones.
The deification of nature is nonsense. It is impossible to find God, based on nature. He is either nature, or He doesn't exist. There's nothing more absurd than to pass off the deification of nature for Christianity" [16]. As for evil, it is not natural, because everything created is good, and evil is a result of will, whether at the cosmic or the human level. In Christianity and other spiritual traditions, evil is personified and absolutely real. It is not a potency, but it is what leads the world and people to disaster and death. Pantheistic reasoning blurs the problem, lulling the conscience of man.

In Russian thought, philosophy of totality borrows pantheistic (Vl. Solovyov) and panentheistic settings (S. Frank defined himself as a disciple of the philosophy of totality and pantheism). "Christian Platonism", that was in development by the so-called "Russian religious philosophy", and even by some philosophers-priests - P. Florensky and S. Bulgakov carries pantheistic features. Metaphysics defines gnoseology. Therefore, pantheistic gnoseology inevitably leads to the devouring of faith by knowledge, i.e., essentially destroying faith in its essence and identity but not so openly, as happens in naturalistic philosophy. All forms of pantheism usually disguise themselves in the robes of Christianity, all the philosophers here somehow tend to swear allegiance to Christianity, in fact denying its fundamental metaphysical principles.

\section{CONCLUSION}

According to A.V. Semushkin, the "existential task is to restore the lost faith of the fathers of the universal "philosophical church", to return to the original life concerns of a person himself". In this case, "faith is an internal experience of a metaphysical feeling", affective "selfquestioning about nature, essence, and purpose". This is the experience of a "living spiritual self-examination", "inquisitive self-trial". Faith is more than philosophy or religion that strive to explain it. According to Heidegger, faith is a "specific existential possibility", preceding theology and philosophy alike. The reveal of an ontological, and, hence, a universal level of faith, provides the foundation for the spiritual unity of the mankind, basing on which the humanity may solve the great global challenges of today, to "unite syntonically the disintegrated mankind" [17]. Faith alone can save people from the animal or barbaric existence and self-destruction. Faith lies in the discoveries of the "Axial Age", in the breakthrough to the transcendent, which is recorded by the world religions, philosophy, and morality.

\section{REFERENCES}

[1] K. Jaspers, Philosophical faith, The Origin and Goal of History. Moscow: Republic, 1994, p. 433.

[2] The Sayings of Confucius. II, 22. [Electronic resource]. URL: http://lunyu.ru/2/22

[3] Bhagavad-Gita. Ashkhabad: Il'um Publisher, 1951, p. 147.

[4] I.V. Kireyevsky, Fragments, in Kireyevsky I.V., Kireyevsky P.V. Complete collection of works. In 4 volumes. Vol. 1. Kaluga: Grif Publisher, 2006, p. 194. 
[5] A.V. Semushkin, "Metaphysic of faith as a problem of cognition (Foreword to monograph)," in Nizhnikov S.A. Metaphysic of faith in Russian philosophy. Moscow: INFRA-M, 2011, p. 3-6.

[6] F.H. Jacobi, "[The last saying to contemporaries]," Chernov S.A. and Shevchenko I.V, Friedrich Jacobi: faith, senses, reason. Moscow: Progress-Tradition, 2010, p. 558.

[7] I.V. Kireyevsky, Fragments, pp. 192-193.

[8] G.V. Florovsky, Human wisdom and Divine wisdom, Of old Russian thoughts. Moscow: Agraf Publisher, 1998, 1998, p. 84.

[9] V.I. Nesmelov, Faith and knowledge from gnoseological point of view. Kazan: Vernisazh Publisher, 1992, p. 4.

[10] V.V. Sokolov, Philosophy as history of philosophy. Moscow: Academical Project, 2010, p. 4.

[11] Al-Ghazali Abū Hāmid, The Revival of Religious Sciences. Selected chapters. Moscow: Science, 1980, p. 203.

[12] S.N. Bulgakov. Light Unfading. Moscow: Republic Publisher, 1994.

[13] F.H. Jacobi, "[The last saying to contemporaries]," p. 557.

[14] A.F. Losev, The History of Classical Aesthetics. In 8 volumes. Vol. 6. Late Hellinism. M.: AST, 2000, pp. 210-211.

[15] F.H. Jacobi "[The last saying to contemporaries]," p. 556.

[16] Ibid., pp. 557-558.

[17] A.V. Semushkin, Philosophical faith of existentialism and its claims for universal ideology, Selected works in 2 volumes, Vol. 2, RUDN, 2009, p. 304. 